\title{
What factors impact Online Education? A factor analysis approach
}

\author{
Vinay Kukreja ${ }^{1}$, Sakshi $^{2}$, Amandeep Kaur ${ }^{3}$, Arun Aggarwal ${ }^{4^{*}}$ \\ $1,2,3$ Chitkara University Institute of Engineering and Technology, ${ }^{4}$ Chitkara Business School, \\ $1,2,3,4$ Chitkara University, Punjab, India. \\ ${ }^{1}$ vinay.kukreja@chitkara.edu.in, ${ }^{2}$ amandeep.kaur@chitkara.edu.in, ${ }^{3}$ sakshi@chitkara.edu.in, ${ }^{4}$ arunaggarwal.mba@gmail.com
}

\begin{abstract}
Internet popularity is growing day by day, which directly or indirectly increases the potential for online study. Apart from this, the current era of COVID 19 has revolutionized online education to a greater extent. However, the usage of computers, software's and technological advancement has raised many questions about the effectiveness of online platforms and online study. This survey-based quantitative study aimed to investigate the factors that affect the success of the online study. A total of 690 participants have participated in the survey attending online classes from multiple institutions in India. After careful investigation, 673 participants survey that was complete in all aspects has been considered for analysis. These students were either graduate/post-graduate or doing graduation/ post-graduate. The data were collected using a structured questionnaire (see Annexure A). Exploratory Factor analysis (EFA) has been conducted to figure out the factors that have positively impacted the students' satisfaction with online study. Confirmatory Factor Analysis (CFA) has been performed to confirm the factors. Results of the structural equation modeling show that instructor quality, course design, ICT orientation, conscientiousness, open-mindedness, and agreeableness have a positive impact and extraversion has a negative impact on the satisfaction of the students. The neurotic type of personality has no impact on the satisfaction of the students.
\end{abstract}

Keywords: Course Design, Instructor Quality, Student Traits, ICT Orientation; Student Satisfaction; Online Classes; COVID 19

\section{Introduction}

At the end of 2019 in Wuhan, China's high-tech industry hubs witnessed an outbreak of a unique coronavirus in the modern era, which killed more than a thousand Chinese in the six weeks of outbreaks and suffered millions of other people. Medical experts designated this fictional virus as COVID-19 fictional coronavirus (Shereen, Khan, Kazmi, Bashir, \& Siddique, 2020). This COVID-2019 expanded internationally later on, in a shorter period. Because of COVID 2019, many countries' economies are significantly impacted. Besides, in the month, this epidemic altered working conditions across the planet.

\section{Corresponding Author \\ Arun Aggarwal, ${ }^{4}$ arunaggarwal.mba@gmail.com}

For so many of the globe's businesses, the effects of the pandemic become inevitable and unmanageable. Later, nearly 120 nations discontinued face-to-face learning; through COVID-19, roughly one billion students' schooling is carried out worldwide. The majority of the university education system functions via e-learning (Azzi-Huck and Shmis, 2020; Shahzad et al., 2020). In the meantime, most of the countries, such as the Indian ministry of education, already signed an order to shut school systems, including postsecondary learning, as an emergency way to reduce the transmission of the infection to overcome the COVID-19 pandemic. Innovations, including Artificial Intelligence (AI) technology, have transformed the conventional schooling method to the modern way of learning (Di Vaio, Boccia, Landriani, \& Palladino, 2020). Via blogs, educational portals, teleconferencing, Twitter, smartphone applications, and thousands of free services for mixed learning materials, e-learning is therefore included underneath a wider concept of technology-based learning. E-learning is currently expanding the knowledge of teachers, including university personnel and technical and business persons, via the web (Roff, 2018; Chopra et al., 2019).

Many colleges in university education deliver classes online for their learners into and out of campuses. The government is offering a lot of money for higher education institutions in India. Indian universities and colleges use massive Open Online Courses (MOOCs). During the projected period from 2016 to 2023, the development of an online learning industry is estimated to be 16.4 percent yearly. Possibly university education - learning structures would be updated in ten to fifteen years with the internet's rapid development. It thus depends on the use of an Elearning portal for boys and girls. Research work focuses on contrasts between females and males peers during the COVID-2019 era upon its utilization of e-learning portals by high school students. Worldwide, owing to the closing and shutdown of COVID-19 epidemic campuses, many students and teachers are delighted with the transition to online learning the academic staff of renowned educational institutions has started to receive accreditations from teacher educators to provide their students with online learning. At almost the same time, faculty and staff members are exploring how and when to use tools for 
online education. Those who use only the distribution by face-to-face instruction beforehand. The change to the single-player portal, though, has raised several concerns about the level of education (Sahu, 2020). Besides, the standard of education and outstanding systems such as computers and modern IT facilities receipt is already in massive demand, and through the use of intellectual resources, universities change their learning methods (Alvino et al., 2020; Di Vaio, Palladino, et al., 2020). Also, the standard of education and outstanding infrastructural facilities such as computing with IT acceptance of modern equipment are already in huge market and academics are changing their teaching models with the use of intellectual resources. Also, the quality of education and excellent infrastructures such as computers and IT reception of modern equipment are now in growing demands and universities are now in high demand. Thus it is necessary to recognize the factors that influence the students' satisfaction with online learning, especially in the context of the COVID 19 outbreak.

\section{Theoretical framework and Hypotheses Development}

The goal orientation hypothesis is a commonly accepted concept within the numerous theories of student's learning (Elliott \& Dweck, 1988) describes that an achieving target includes a programme of cognitive processes that have cognitive, affective, and behavioral implications. This hypothesis indicates that the intent and explanations can readily interpret students' achievement and motivation related habits for their involvement in learning practices (Dweck \& Legget, 1988; Ames, 1992; Urdan, 1997). Various researchers revealed four paths to reaching a goal: mastery strategy, avoiding mastery, success plan, and avoiding success (Pintrich, 1999); (Andrew, 2001). The environment also impacts students ' success (Ziglari \& Yahya, 1988). Historically, instruction throughout the class is among the most successful approaches for achieving the purpose (Ziglari \& Yahya, 1988; Ames, 1992). However, internet-based education is one of the powerful methods for offering modern teaching times, and digital classes are becoming web-based apps (Gallagher \& Newman, 2002); Competency-based factors and self-based factors contribute to targets of accomplishment, as well as the targets of achievement further contribute to procedures and performance (Elliot, 1999; Pekrun, 2006). It offers the fresher framework to visualize the student's results that relies on result expectations of circumstance whenever a student does not make attempts to pass the examination. Yet, there are higher risks of failure in the test. The scenario may generate undesirable results, some moments without peer-action or another time to take action seeing the expectations of the result (Bolles, 1972; Heckhausen, 1977) if the operation of learning is evaluated favorably, so it ends in an efficient instrument for accomplishment and success (Csikszentmihalyi, 2000).

A. Instructor quality and satisfaction of the students
The standard of an extremely fanatical teacher in students' education has a significant impact on their satisfaction level. Among the most critical indicators for students' satisfaction is teacher efficiency (Munteanu, Ceobanu, Bobâlcă, \& Anton, 2010). Teacher performance's task significantly impacts producing students' satisfaction (Arambewela \& Hall, 2009). The educator's quality is an important requisite of students' satisfaction, which also results in the outcome of the process of education (Ramsden, 1991). Educators have a critical role in shaping student success. (Maina 2010) concluded that the main objective is to enhance the student's performance that contributes to the successful growth. The idea that the consistency of a teacher has a substantial impact on the satisfaction of the learners was also included in the study.

H1: Instructor quality has a positive impact on the satisfaction level of students.

\section{B. Course design and satisfaction of students}

In a section of the course, technical architecture strongly persuades learners to study and fulfill themselves by specific course demands (Liaw, 2008; Lin et al., 2008). Compared with conventional design, a successful course layout shows the students' productive results (Black et al., 2004). For successful course design, the method of learning is critical (Wooldridge \& Jennings, 1995). It is important to note that we have created an environment for students with varying teaching strategies when designing an online course layout. Similarly, the illustrated course design feature may be created and used to boost student performance skills. Therefore, the premise that the course design has a substantial effect on student success was used in this report.

$\mathrm{H} 2$ : Course design has a positive impact on the satisfaction level of students.

\section{Technology and Satisfaction of Students}

ICT lets institutions meet the expectations of perceived service efficiency throughout this pandemic. ICT also lets universities to maintain their students satisfied and optimistic about the services that they offer. In this way, universities' ICT orientation tends to lead to satisfaction among the student because it encourages the institution to provide students perceptions that the institution is worried about their needs so that the real resources offered by an organization/university match their standards services. The "anticipated behavior hypothesis" implies that external influences, beliefs, expectations, and perceived behavioral factors of clients form and steer their emotions, behavior, and desires toward that brand (Ajzen, 2015; Chu et al., 2016; Kalafatis et al., 1999). This implies if clients/students trust that perhaps the university provides them with upgraded services using the new technologies. Therefore, they will be more inclined to have favorable emotions towards the university, which improves their happiness with the university. Consequently, this is stated that education in information \& communication technologies efficiently plays a significant role in growing student overall satisfaction. The effect of ICT use on student 
success and their happiness throughout history has been investigated by numerous research. For example, (Shinn, Poston, Kimball, St. Jeor, \& Foreyt, 2001) proposed that the use of ICT today increases students' skills, learning, and happiness while providing the ability to access an innovative and revised education system. The importance of using ICT in the educational process to boost students' satisfaction also was investigated by (Biasutti \& ElDeghaidy, 2012), they demonstrate that the use of ICT in the education sector contributes to greater student success as it encourages the organization and provides students with improved tools and facilities. Researches by (Endres et al., 2009; Manochehri \& Young, 2006; Mitić et al., 2017; Gray \& DiLoreto, 2016) provide experimental evidence for the present claim that organizations/universities will support them achieve greater customer loyalty by advanced ICT. These findings, however, have not effectively clarified whether or not ICT will specifically improve students ' satisfaction with universities. The current research, therefore, hypothesizes that:

H3: ICT orientation has a positive impact on the satisfaction level of students.

\section{Student's Traits and student satisfaction}

Personality characteristics are conceptualized as directly relating actions, intellect, and emotional behaviors, representing the propensity to react in certain conditions in many ways (Zanotti, Looze, Roberts, \& Barnekow, 2009). The Major Five character characteristics often emerged as significant factors of human personality in recent months (Eysenck, 1992; Hofstee et al., 1992; Mccrae \& Costa, 1999), including reference to a large variety of areas, like schooling (Poropat, 2009). The preceding qualities are found throughout the big-five personalities: extraversion, agreeability, conscientiousness, negative emotionality, and open-mindedness. Extraverted people have an enthusiastic attitude to life, exhibit outgoing and socially adept behavior, which usually appear to have optimistic feelings. People who score high on acceptability are considerate, caring, supportive, pro-social in specific, and ready to delegate their individual preferences. Conscientiousness is related to the way people manage, manage, and sends signals. A perceiving score means becoming goal-oriented, consistent, saintly, coordinated, and complying with expectations and regulations. The emotional health of a person and elements of anxiety, unease, and feelings of insecurity are characterized by negative emotionality. Neurotic patients tend to be susceptible to negative feelings. The openminded, imaginative, scientifically active, and usually engaged in new opportunities and concepts are persons that score high on open-mindedness.

The research to help one to infer specific theories relevant to the possible role of the Major Five personality characteristics throughout the COVID-19 issue, including school closing classroom activities and perceptions, is shown in Fig. 1. Learners with good extrovert levels derive energy from being around people. Consequently, leading to a shortage of social contact, we believe that they may have faced additional trouble during the crisis. On the other hand, this situation may have given a break from the stressful consequences of social contact for introverted students.

For a prolonged period, Flemish students had to study from home due to the closing of classrooms. Online learning requires learning techniques of self-control, like time control and management of commitment, that are linked to high negative emotionality (Bidjerano \& Dai, 2007). As a result, we believe the students with a higher degree of knowledge have taken ownership of the learning and have established a more favorable view of virtual learning. Throughout the online education sense, this will be consistent with previous findings (Keller \& Karau, 2013); (Cohen \& Baruth, 2017).

The confusion associated with crisis and school closing may have been unattractive to students ranking high on conscientiousness, the one most prone to anxiety and fear (Keller \& Karau, 2013). Besides, it is observed that conscientiousness (negatively) influences the nature of the relationship between younger people and their guardians (Belsky, Jaffee, Caspi, \& Moffitt, 2003). Therefore, since students would have to spend longer during the COVID-19 crisis with their parents and family, we believe that students with elevated conscientiousness feel more depressed than others.

As in the case of the COVID-19 crisis, the more transparent, the best a person deals with ambiguity over a long, prolonged time. Students with a strong open-mindedness level appreciate participating in new activities (learning) (Keller \& Karau, 2013). We expect, thus, that all these students have learned from the current scenario. It is less evident from available research to hypothesize how compatibility will change the way students viewed the crisis and online learning. Agreeability is thought to associate with volunteer work and social competence (Ozer $\&$ Benet-Martínez, 2006). Therefore, we can believe that people who rank high on compatibility are much more likely than most to support others during the crisis, within and/or beyond their households.

H4a: The personality of an extrovert has a negative effect on students' satisfaction levels for online classes.

H4b: Conscientiousness Personality has a positive effect on students' satisfaction level for online classes.

H4c: Negative emotionality personality has a negative impact on students' satisfaction levels for online courses.

H4d: Open-mindedness to experience has a positive effect on students' satisfaction levels for online classes.

H4e: Agreeableness personality has a positive effect on students' satisfaction levels for online classes. 


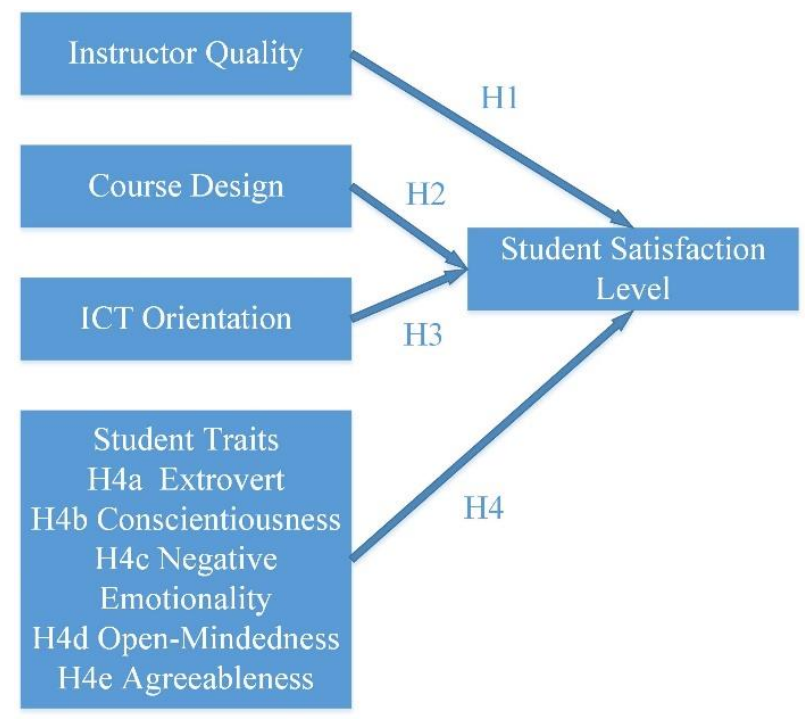

Fig. 1 Conceptual Model

\section{Research Methodology}

\section{A. Measure}

This study is quantitative, and a survey has been conducted that consists of two sections. The first section consists of demographic profiles whereas the other section measures five factors, namely course design, instructor quality, student traits ("extraversion, agreeableness, conscientiousness, negative emotionality and openmindedness"), ICT orientation ("ease of use; advantage, compatibility, and perception") and students' satisfaction with online classes. Here, the dependent variable is satisfaction, whereas the other four are independent variables. These variables are taken into account with the help of previous studies (Chickering \& Gamson, 1987; Wilson, Lizzio \& Ramsden, 1997; Bangert, 2004; Bhat and Basshir, 2018). The five-point Likert scale is used for measuring these variables, where one stands for strongly disagrees to five stands for strongly agree. The respondents belong to India, and the survey has a total of fifty-nine questions. The survey is conducted to know the effect of four independent variables on the satisfaction level of students. The Big-2-S version of the big-five personality dimension developed by Soto and John (Soto \& John, 2017) is used in the present study. For measuring student's traits, a 5-point Likert scale was used where one denotes completely untrue, and five denotes completely true. The student's traits include dimensions like Open-Mindedness, Negative Emotionality, Agreeableness, Extraversion, and Conscientiousness. Each dimension is further measured based on six items, respectively.

To measure the ICT orientation dimension, a scale developed by Bhat and Basshir (2018) is used. A total of sixteen items are present on this scale. The five items are associated with ease of use. Four items are used for compatibility and advantage, respectively, whereas three items are associated with perception variables.

\section{B. Data Collection}

To do the quantitative work, a survey was conducted, and that has been performed with the help of google forms. The links were shared on Facebook, WhatsApp groups, as well as through e-mails. The students of different universities operating in India were invited to participate in the survey. The sampling technique used for the survey is convenience sampling. The survey is cross-sectional, and 426 undergraduate and 247 post-graduate have participated in this online survey. The percentage of participation is $63.29 \%$ and $36.71 \%$ for undergraduate and post-graduate, respectively. The survey has been conducted between June 2020 to September 2020. Table 1 shows the respondents' profile.

Table 1. Respondents' Profile

\begin{tabular}{|l|l|l|}
\hline Categories & Item & Percentage \\
\hline Gender & Male & 52.45 \\
& Female & 47.55 \\
\hline Education & Undergraduate & 63.29 \\
& Post-graduate & 36.71 \\
\hline Age & $18-21$ & 52.00 \\
& $22-25$ & 19.29 \\
& Above 25 & 29.71 \\
\hline Family Income & 0-2.5 Lakhs & 29.71 \\
& 2.51 to 5 Lakhs & 38.64 \\
& 5 Lakhs to 10 Lakhs & 23.77 \\
& 10 Lakhs and Above & 07.88 \\
\hline Area of living & Rural & 66.8 \\
& Urban & 33.2 \\
\hline
\end{tabular}

\section{Data Analysis}

EFA, CFA, and PLS-SEM were used to test the proposed hypothesis. EFA was used to extract the factors associated with online education, whereas CFA was used to validate the factors extracted by EFA. The CFA confirms the five factors that impact online education. In the end, to analyze the relationship, partial least squares-structural equation modeling (PLS-SEM) was used.

The EFA was used to extract the factors by seeing the eigenvalues as well as it helps in knowing whether items were loaded in the extracted corresponding factors correctly (Hair et al., 2016). Fifty-Nine variables were identified and considered that affect student's satisfaction levels in the case of online education. After doing data analysis, 12 factors (including sub-factors) have been found, and these factors explained $71.5 \%$ of the total variance. Harman's single-factor has been used to testify the common method bias. Exploratory factor investigation has been performed, and an unrotated factor arrangement was witnessed and examined. For all 59 variables, that have been identified, principal components analysis (PCA) has been performed that resulted in 12 factors with eigenvalues greater than 1 (12.8\% of the variance is achieved for the first factor) that helps in knowing that there are no issues in common method bias (Jarvis et al., 2003).

\section{A. Measurement Model}

The two-step method was used to confirm the convergent validity, as suggested by Fornell and Larcker (1981). In the first step, standardized factor loadings (SFL) were checked. 
These should be more than 0.7 , and a significant level is checked at 0.05. In the second step, the average variance extracted (AVE) is checked for all the latent variables, and it should be more than 0.5 for all. Next, composite reliability $(\mathrm{CR})$ is checked. It must be more than 0.7 as well as CR should be more than AVE for all latent variables (Aggarwal, Dhaliwal and Nobi, 2018; Aggarwal, Goyal and Nobi, 2018). Table 1 shows that the SFL for all items is more than 0.6. The value lies between 0.687 to 0.834 . AVE values lie between 0.522 to 0.592 for all latent variables. Table 2 shows that convergent validity has been achieved for the measurement model (Aggarwal, Goyal, Nobi, 2018).

Table 2: Factor loadings and reliability

\begin{tabular}{|l|l|l|l|}
\hline Factors & $\begin{array}{l}\text { Final } \\
\text { standardized } \\
\text { loadings }\end{array}$ & $\begin{array}{l}\text { Composite } \\
\text { construct } \\
\text { reliability }\end{array}$ & $\begin{array}{l}\text { Average } \\
\text { variance } \\
\text { extracted }\end{array}$ \\
\hline $\begin{array}{l}\text { Instructor } \\
\text { Quality }\end{array}$ & & 0.904 & 0.574 \\
\hline IQ1 & 0.707 & & \\
\hline IQ2 & 0.720 & & \\
\hline IQ3 & 0.741 & & \\
\hline IQ4 & 0.754 & & \\
\hline IQ5 & 0.797 & & \\
\hline IQ6 & 0.767 & & \\
\hline IQ7 & 0.812 & & \\
\hline Course Design & & 0.773 & 0.536 \\
\hline CD1 & 0.726 & & \\
\hline CD2 & 0.701 & & \\
\hline CD3 & 0.714 & & \\
\hline CD4 & 0.824 & & \\
\hline CD5 & 0.687 & & \\
\hline CD6 & 0.734 & & \\
\hline ICT Orientation & & 0.753 & \\
\hline Ease of Use & 0.753 & \\
\hline EOU1 & 0.708 & & \\
\hline EOU2 & 0.756 & & \\
\hline EOU3 & 0.714 & & \\
\hline EOU4 & & & \\
\hline EOU5 & 0.714 & & \\
\hline Advantage & & & \\
\hline ADV1 & & & \\
\hline ADV2 & & & \\
\hline ADV3 & & & \\
\hline ADV4 & & & \\
\hline Compatibility & & & \\
\hline COM1 & & & \\
\hline
\end{tabular}

\begin{tabular}{|c|c|c|c|}
\hline COM4 & 0.726 & & \\
\hline \multicolumn{2}{|c|}{ Perception } & 0.794 & 0.563 \\
\hline PER1 & 0.754 & & \\
\hline PER2 & 0.715 & & \\
\hline PER3 & 0.781 & & \\
\hline \multicolumn{2}{|c|}{ Student Traits } & & \\
\hline \multicolumn{2}{|c|}{ Extraversion } & 0.892 & 0.580 \\
\hline EXT1 & 0.738 & & \\
\hline EXT2 & 0.719 & & \\
\hline EXT3 & 0.786 & & \\
\hline EXT4 & 0.702 & & \\
\hline EXT5 & 0.824 & & \\
\hline EXT6 & 0.794 & & \\
\hline \multicolumn{2}{|c|}{ Agreeableness } & 0.897 & 0.592 \\
\hline AGR1 & 0.834 & & \\
\hline AGR2 & 0.784 & & \\
\hline AGR3 & 0.782 & & \\
\hline AGR4 & 0.742 & & \\
\hline AGR5 & 0.704 & & \\
\hline AGR6 & 0.768 & & \\
\hline \multicolumn{2}{|c|}{ Conscientiousness } & 0.885 & 0.564 \\
\hline CON1 & 0.688 & & \\
\hline CON2 & 0.746 & & \\
\hline CON3 & 0.816 & & \\
\hline CON4 & 0.709 & & \\
\hline CON5 & 0.761 & & \\
\hline CON6 & 0.779 & & \\
\hline \multicolumn{2}{|c|}{ Negative Emotionality } & 0.879 & 0.549 \\
\hline NEU1 & 0.772 & & \\
\hline NEU2 & 0.749 & & \\
\hline NEU3 & 0.764 & & \\
\hline NEU4 & 0.715 & & \\
\hline NEU5 & 0.734 & & \\
\hline NEU6 & 0.709 & & \\
\hline \multicolumn{2}{|c|}{ Open-Mindedness } & 0.894 & 0.585 \\
\hline OPN1 & 0.824 & & \\
\hline OPN2 & 0.784 & & \\
\hline OPN3 & 0.705 & & \\
\hline OPN4 & 0.743 & & \\
\hline OPN5 & 0.765 & & \\
\hline OPN6 & 0.764 & & \\
\hline
\end{tabular}

\section{B. Structural Model}

Structural Equation Modeling (SEM) has been used for doing path analysis (Ringle, Wende, and Will, 2005). The tool used for doing path analysis was SmartPLS 2.0. The 
factor weighting was calculated due to the robustness of the model. The results showed that the proposed model is valid and adequately explains the factors that impact online education. The 0.053 standardized root means square residual (SRMR) was found far below the critical value of 0.085 and confirms the good explanatory power of the proposed model (Henseler et al., 2016).

Table 3: Hypothesized relationships

\begin{tabular}{|l|ll|l|l|l|}
\hline & Relationship & & Std $\boldsymbol{\beta}$ & $\mathbf{t}$-value & Decision \\
\hline $\mathrm{H} 1$ & $\begin{array}{l}\text { Instructor Quality } \\
\text { Satisfaction }\end{array}$ & $\rightarrow$ & 0.312 & $6.421^{* *}$ & Supported \\
\hline $\mathrm{H} 2$ & $\begin{array}{l}\text { Course Design } \\
\text { Satisfaction }\end{array}$ & $\rightarrow$ & 0.225 & $4.424^{* *}$ & Supported \\
\hline $\mathrm{H} 3$ & $\begin{array}{l}\text { ICT Orientation } \\
\text { Satisfaction }\end{array}$ & $\rightarrow$ & 0.294 & $5.978^{* *}$ & Supported \\
\hline $\mathrm{H} 4 \mathrm{a}$ & Extraversion $\rightarrow$ Satisfaction & -0.254 & $-5.242^{* * *}$ & Supported \\
\hline $\mathrm{H} 4 \mathrm{~b}$ & $\begin{array}{l}\text { Conscientiousness } \\
\text { Satisfaction }\end{array}$ & $\rightarrow$ & 0.275 & $5.695^{* *}$ & Supported \\
\hline $\mathrm{H} 4 \mathrm{c}$ & $\begin{array}{l}\text { Negative emotionality } \\
\text { Satisfaction }\end{array}$ & $\rightarrow$ & -0.094 & 1.198 & $\begin{array}{l}\text { Not } \\
\text { Supported }\end{array}$ \\
\hline H4d & $\begin{array}{l}\text { Open-mindedness } \\
\text { Satisfaction }\end{array}$ & $\rightarrow$ & 0.198 & $3.547^{* *}$ & Supported \\
\hline H4e & $\begin{array}{l}\text { Agreeableness } \\
\text { Satisfaction }\end{array}$ & $\rightarrow$ & 0.205 & $3.982^{* *}$ & Supported \\
\hline Note: **Significant at the p<0.01 level & & \\
\hline
\end{tabular}

The results of table 3 show the relationship between the study variables. Results show a significant and positive impact of instructor quality on the students' satisfaction towards online classes during the COVID 19 pandemic. The path analysis results show that course design has a positive and significant impact on the students' satisfaction with online classes. Findings of table 2 manifested that there is a positive and significant impact of ICT orientation on students' satisfaction towards online classes. In addition to this, the path analysis results show that there is a negative and significant impact of extrovert personality on the students' satisfaction towards online classes. The path analysis results depicted a positive and significant impact of conscientiousness on the students' satisfaction towards online classes. However, results show no significant impact of neurotic personality on the students' satisfaction towards online classes as the p-value of this relationship is less than 0.05 level of significance. Further, the path analysis results manifested that there is a positive and significant impact of open-mindedness personality on the students' satisfaction towards online classes. Finally, the structural equation modeling results manifested that there is a positive and significant impact of agreeableness type of personality on the students' satisfaction towards online classes.

\section{Discussion and Conclussion}

The present study aimed to identify the factors that affect the student's satisfaction with online classes during COVID 19 pandemic. To achieve this objective, an extensive literature review was conducted, and four important factors were identified that affect the student's satisfaction with online classes. The first factor was the instructor quality. Educators have a critical role in shaping student success. (Maina 2010) concluded that the main objective of a teacher is to enhance the student's performance that contributes to the successful growth. The second factor that affects the student's satisfaction with online classes was course design. Various authors have concluded that compared with conventional design, a successful course layout shows the students' productive results better. The second factor that affects the student's satisfaction with online classes was ICT orientation (Technology).

Numerous researches have investigated the impact of ICT orientation on student success and their satisfaction. For example, (Shinn et al., 2001) proposed that the use of ICT increases students' skills, learning, and happiness while providing the ability to access an innovative and revised education system. The importance of using ICT in the educational process to boost students' satisfaction also was investigated by (Biasutti \& El-Deghaidy, 2012). They demonstrate that using ICT in the education sector contributes to tremendous student success as it encourages the organization and provides students with improved tools and facilities. Finally, the present research identifies the student's traits (personality) as an essential variable that affects the student's satisfaction with online classes. In the current study, the student traits were examined under the umbrella of big-five personality dimensions ("extraversion, agreeability, conscientiousness, negative emotionality, and open-mindedness"). The findings of the current study show that instructor quality has a significant and positive impact on students' satisfaction towards online classes during the COVID 19 pandemic. The study showed a positive relationship between course design and student's satisfaction with online classes.

Further, the findings of analysis manifested a positive and significant impact of ICT orientation on the students' satisfaction towards online classes. The findings of the study show that personality of a student plays an import role in affecting the satisfaction of the students towards online classes. Extrovert and neurotic personality type of the students has negative effect on their satisfaction level towards online classes. However, Conscientiousness, Openmindedness and Agreeableness types of the personality has positive relationship with student's satisfaction with online classes. The findings of the SEM analysis show that instructor quality is the most important factor that affect the satisfaction of the student. These findings will help the the educational institute to increase the satisfaction level of the students, especially in online classes by recruiting and retaining the instructors who are good in subject knowledge and teaching. 


\section{References}

Aggarwal, A., Dhaliwal, R. S., \& Nobi, K. (2018). Impact of structural empowerment on organizational commitment: the mediating role of women's psychological empowerment. Vision, 22(3), 284-294.

Aggarwal, A., Goyal, J., \& Nobi, K. (2018). Examining the Impact of Leader-Member Exchange on Perceptions of Organizational Justice: The Mediating Role of Perceptions of Organizational Politics. Theoretical Economics Letters, 8(11), 2308-2329.

Ajzen, I. (2015). Consumer attitudes and behavior: the theory of planned behavior applied to food consumption decisions. Italian Review of Agricultural Economics, 70(2), 121-138.

Alvino, F., Di Vaio, A., Hassan, R., \& Palladino, R. (2020). Intellectual capital and sustainable development: A systematic literature review. Journal of Intellectual Capital, 11(12), 1-19.

Ames, C. (1992). Classrooms: Goals, Structures, and Student Motivation, 84(3), 261-271.

Andrew j. Elliot. (2001). A 2*2 Achievement Goal Framework. Journal of Personality and Social Psychology, 80(3), 501-519.

Arambewela, R., \& Hall, J. (2009). An empirical model of international student satisfaction. Asia Pacific Journal of Marketing and Logistics, 21(4), 555-569.

Biasutti, M., \& El-Deghaidy, H. (2012). Using Wiki in teacher education: Impact on knowledge management processes and student satisfaction. Computers and Education, 59(3), 861-872.

Bidjerano, T., \& Dai, D. Y. (2007). The relationship between the big-five model of personality and selfregulated learning strategies. Learning and Individual Differences, 17(1), 69-81.

Chopra, G., Madan, P., Jaisingh, P., \& Bhaskar, P. (2019). Effectiveness of e-learning portal from students' perspective: A structural equation model (SEM) approach. Interactive Technology and Smart Education, 16(2), 94-116.

Cohen, A., \& Baruth, O. (2017). Personality, learning, and satisfaction in fully online academic courses. Computers in Human Behavior, 72(2), 1-12.

Csikszentmihalyi, M. (2000). The costs and benefits of consuming. Journal of Consumer Research, 27(2), 267-272.
Di Vaio, A., Boccia, F., Landriani, L., \& Palladino, R. (2020). Artificial intelligence in the agri-food system: Rethinking sustainable business models in the COVID-19 scenario. Sustainability (Switzerland), 12(12), 1-12.

Di Vaio, A., Palladino, R., Hassan, R., \& Alvino, F. (2020). Human resources disclosure in the EU Directive 2014/95/EU perspective: A systematic literature review. Journal of Cleaner Production, 257(10), 120509.

Elliott, E. S., \& Dweck, C. S. (1988). Goals: An Approach to Motivation and Achievement. Journal of Personality and Social Psychology, 54(1), 5-12.

Endres, M. L., Chowdhury, S., Frye, C., \& Hurtubis, C. A. (2009). The Multifaceted Nature of Online MBA Student Satisfaction and Impacts on Behavioral Intentions. Journal of Education for Business, 84(5), 304-312.

Eysenck, H. J. (1992). Four ways five factors are not basic. Personality and Individual Differences, 13(6), 667673.

Gray, J. A., \& DiLoreto, M. (2016). The Effects of Student Engagement, Student Satisfaction, and Perceived Learning in Online Learning Environments This. NCPEA International Journal of Educational Leadership Preparation, 11(1), 98-119.

Heckhausen, H. (1977). Achievement motivation and its constructs: A cognitive model. Motivation and Emotion, 1(4), 283-329.

Hofstee, W. K. B., de Raad, B., \& Goldberg, L. R. (1992). Integration of the Big Five and Circumplex Approaches to Trait Structure. Journal of Personality and Social Psychology, 63(1), 146-163.

Kalafatis, S. P., Pollard, M., East, R., \& Tsogas, M. H. (1999). Green marketing and Ajzen's theory of planned behaviour: A cross-market examination. Journal of Consumer Marketing, 16(5), 441-460.

Keller, H., \& Karau, S. J. (2013). The importance of personality in students' perceptions of the online learning experience. Computers in Human Behavior, 29(6), 2494-2500.

Liaw, S. S. (2008). Investigating students' perceived satisfaction, behavioral intention, and effectiveness of e-learning: A case study of the Blackboard system. Computers and Education, 51(2), 864-873.

Lin, Y. M., Lin, G. Y., \& Laffey, J. M. (2008). Building a social and motivational framework for understanding 
satisfaction in online learning. Journal of Educational Computing Research, 38(1), 1-27.

Maina, E. K. (2010). The Communications Commission of Kenya, 1-68.

Manochehri, N. N., \& Young, J. I. (2006). The Impact of Student Learning Styles With Web-Based Learning or Instructor-Based Learning on Student Knowledge and Satisfaction. Quarterly Review of Distance Education, 7(3), 313-316.

Mccrae, R. R., \& Costa, P. T. (1999). The five-factor theory of personality. In O. P. John, R. W. Robins, \& L. A. Pervin (Eds.), Handbook of personality: Theory and research, The Guilford Press, 159-181.

Mitić, S., Nikolić, M., Jankov, J., Vukonjanski, J., \& Terek, E. (2017). The impact of information technologies on communication satisfaction and organizational learning in companies in Serbia. Computers in Human Behavior, 76(7), 87-101.

Munteanu, C., Ceobanu, C., Bobâlcă, C., \& Anton, O. (2010). An analysis of customer satisfaction in a higher education context. International Journal of Public Sector Management, 23(2), 124-140.

Ozer, D. J., \& Benet-Martínez, V. (2006). Personality and the prediction of consequential outcomes. Annual Review of Psychology, 57(8), 401-421.

Black, P., Harrison, C., Lee, C., Marshall, B., \& Wiliam, D. (2004). Working inside the black box: Assessment for learning in the classroom. Phi delta kappan, 86(1), 8-21.

Pekrun, R. (2006). The control-value theory of achievement emotions: Assumptions, corollaries, and implications for educational research and practice. Educational Psychology Review, 18(4), 315-341.

Pintrich, P. R. (1999). The role of motivation in promoting and sustaining self-regulated learning. International Journal of Educational Research, 31(6), 459-470.

Ramsden, P. (1991). A Performance Indicator of Teaching Quality in Higher Education: The Course Experience Questionnaire. Studies in Higher Education, 16(2), 129-150.

Roff, K. A. (2018). Student Satisfaction and/or Dissatisfaction in Blended Learning Environments. Frontiers in Education Technology, 1(2), 149.

Shahzad, A., Hassan, R., Aremu, A. Y., Hussain, A., \& Lodhi, R. N. (2020). Effects of COVID-19 in Elearning on higher education institution students: the group comparison between male and female. Quality and Quantity, 7(0123456789), 1-22.
Shereen, M. A., Khan, S., Kazmi, A., Bashir, N., \& Siddique, R. (2020). COVID-19 infection: Origin, transmission, and characteristics of human coronaviruses. Journal of Advanced Research, 24(4), 91-98.

Shinn, E. H., Poston, W. S. C., Kimball, K. T., St. Jeor, S. T., \& Foreyt, J. P. (2001). Blood pressure and symptoms of depression and anxiety: A prospective study. American Journal of Hypertension, 14(7 I), 660-664.

Soto, C. J., \& John, O. P. (2017). Short and extra-short forms of the Big Five Inventory-2: The BFI-2-S and BFI-2-XS. Journal of Research in Personality, 68, 69-81.

Urdan, T. C. (1997). Examining the relations among early adolescent students' goals and friends' orientation toward effort and achievement in school. Contemporary Educational Psychology, 22(2), 165191.

Wooldridge, M., \& Jennings, N. R. (1995). Wooldridge Jennings.pdf. Knowledge Eng. Rev., 10(2), 115-152.

Zanotti, C., Looze, M. De, Roberts, C., \& Barnekow, V. (2009). Social_determinants_of_health_and_wellb20151111-27604-w42wjb.

Ziglari, H., \& Yahya, S. (1988). Deployment models: Enhancing security in cloud computing environment. Proceedings - Asia-Pacific Conference on Communications, APCC 2016, 80(3), 204-209. 


\section{Annexure A: Questionnaire}

\begin{tabular}{|c|c|c|}
\hline Scale & Factor & Items \\
\hline \multirow[t]{12}{*}{$\begin{array}{l}\text { ICT } \\
\text { orientati } \\
\text { on }\end{array}$} & Advantage & $\begin{array}{l}\text { ICT based methodologies } \\
\text { promote a conducive } \\
\text { teaching and learning } \\
\text { environment }\end{array}$ \\
\hline & & $\begin{array}{l}\text { Use of the ICT based } \\
\text { methodologies raise the } \\
\text { curriculum standards }\end{array}$ \\
\hline & & $\begin{array}{l}\text { ICT based methodologies } \\
\text { are positively correlated } \\
\text { with the academic } \\
\text { performance of students }\end{array}$ \\
\hline & & $\begin{array}{l}\text { Usage of ICT based } \\
\text { methodologies brings } \\
\text { positive change in the } \\
\text { classroom }\end{array}$ \\
\hline & $\begin{array}{l}\text { Compatibili } \\
\text { ty }\end{array}$ & $\begin{array}{l}\text { ICT based methodologies } \\
\text { are very supportive in } \\
\text { developing } \\
\text { my working style }\end{array}$ \\
\hline & & $\begin{array}{l}\text { Availability of } \text { ICT } \\
\text { resources increases my } \\
\text { productivity and } \\
\text { professional effectiveness }\end{array}$ \\
\hline & & $\begin{array}{l}\text { ICT enabled teaching is } \\
\text { better than traditional } \\
\text { methods of } \\
\text { Teaching }\end{array}$ \\
\hline & Ease of Use & $\begin{array}{l}\text { Online surfing of learning } \\
\text { material makes my students } \\
\text { more } \\
\text { effective day by day }\end{array}$ \\
\hline & & $\begin{array}{l}\text { ICT enabled teaching } \\
\text { methodologies to build } \\
\text { confidence for the } \\
\text { preparation } \\
\text { presentation of lectures and }\end{array}$ \\
\hline & & $\begin{array}{l}\text { It is easier to communicate } \\
\text { through ICT applications } \\
\text { like online quizzes, } \\
\text { educational blogs \& } \\
\text { common e-mails }\end{array}$ \\
\hline & & $\begin{array}{l}\text { It is convenient to share } \\
\text { assignments, lecture notes } \\
\text { and study material through } \\
\text { ICT }\end{array}$ \\
\hline & & $\begin{array}{l}\text { Different } \\
\text { preferences and styles of } \\
\text { students are properly } \\
\text { handled with the help of }\end{array}$ \\
\hline
\end{tabular}

\begin{tabular}{|c|c|c|}
\hline & & ICT \\
\hline & Perception & $\begin{array}{l}\text { ICT usage costs physical } \\
\text { and social activities }\end{array}$ \\
\hline & & 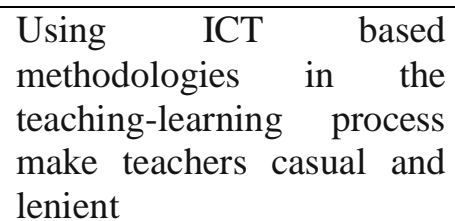 \\
\hline & & $\begin{array}{l}\text { ICT provides my students } \\
\text { with opportunities to } \\
\text { plagiarize content using } \\
\text { copy \& paste }\end{array}$ \\
\hline \multirow[t]{19}{*}{$\begin{array}{l}\text { Big- } \\
\text { Five } \\
\text { Personal } \\
\text { ity } \\
\text { Dimensi } \\
\text { ons } \\
\end{array}$} & $\begin{array}{l}\text { Extraversio } \\
\mathrm{n}\end{array}$ & Tends to be quiet (R) \\
\hline & & $\begin{array}{l}\text { Is dominant, acts as a } \\
\text { leader }\end{array}$ \\
\hline & & Is full of energy \\
\hline & & Is outgoing, sociable \\
\hline & & $\begin{array}{l}\text { Prefers to have others take } \\
\text { charge }(\mathrm{R})\end{array}$ \\
\hline & & $\begin{array}{l}\text { Is less active than other } \\
\text { people }(\mathrm{R})\end{array}$ \\
\hline & $\begin{array}{l}\text { Agreeablen } \\
\text { ess }\end{array}$ & $\begin{array}{l}\text { Is compassionate, has a soft } \\
\text { heart }\end{array}$ \\
\hline & & $\begin{array}{l}\text { Is sometimes rude to others } \\
\text { (R) }\end{array}$ \\
\hline & & $\begin{array}{l}\text { Assumes the best about } \\
\text { people }\end{array}$ \\
\hline & & $\begin{array}{l}\text { Can be cold and uncaring } \\
\text { (R) }\end{array}$ \\
\hline & & $\begin{array}{l}\text { Is respectful, treats others } \\
\text { with respect }\end{array}$ \\
\hline & & $\begin{array}{l}\text { Tends to find fault with } \\
\text { others }(\mathrm{R})\end{array}$ \\
\hline & $\begin{array}{l}\text { Conscientio } \\
\text { usness }\end{array}$ & $\begin{array}{l}\text { Tends to be disorganized } \\
\text { (R) }\end{array}$ \\
\hline & & $\begin{array}{l}\text { Has difficulty getting } \\
\text { started on tasks (R) }\end{array}$ \\
\hline & & $\begin{array}{l}\text { Is reliable, can always be } \\
\text { counted on }\end{array}$ \\
\hline & & Keeps things neat and tidy \\
\hline & & $\begin{array}{l}\text { Is persistent, works until } \\
\text { the task is finished }\end{array}$ \\
\hline & & $\begin{array}{l}\text { Can be somewhat careless } \\
\text { (R) }\end{array}$ \\
\hline & $\begin{array}{l}\text { Negative } \\
\text { Emotionalit } \\
\mathrm{y}\end{array}$ & Worries a lot \\
\hline
\end{tabular}




\begin{tabular}{|c|c|c|}
\hline & & $\begin{array}{l}\text { Tends to feel depressed, } \\
\text { blue }\end{array}$ \\
\hline & & $\begin{array}{l}\text { Is emotionally stable, not } \\
\text { easily upset }(\mathrm{R})\end{array}$ \\
\hline & & $\begin{array}{l}\text { Is relaxed, handles stress } \\
\text { well }(R)\end{array}$ \\
\hline & & $\begin{array}{l}\text { Feels secure, comfortable } \\
\text { with self }(\mathrm{R})\end{array}$ \\
\hline & & $\begin{array}{l}\text { Is temperamental, gets } \\
\text { emotional easily }\end{array}$ \\
\hline & $\begin{array}{l}\text { Open- } \\
\text { Mindednes } \\
\text { s }\end{array}$ & $\begin{array}{l}\text { Is fascinated by art, music, } \\
\text { or literature }\end{array}$ \\
\hline & & $\begin{array}{l}\text { Has little interest in abstract } \\
\text { ideas (R) }\end{array}$ \\
\hline & & $\begin{array}{l}\text { Is original, comes up with } \\
\text { new ideas }\end{array}$ \\
\hline & & $\begin{array}{l}\text { Has few artistic interests } \\
\text { (R) }\end{array}$ \\
\hline & & Is complex, a deep thinker \\
\hline & & Has little creativity (R) \\
\hline \multirow{7}{*}{$\begin{array}{l}\text { Instruct } \\
\text { or } \\
\text { Quality }\end{array}$} & & $\begin{array}{l}\text { The instructor } \\
\text { communicated effectively }\end{array}$ \\
\hline & & $\begin{array}{l}\text { The instructor was } \\
\text { enthusiastic about online } \\
\text { teaching }\end{array}$ \\
\hline & & $\begin{array}{l}\text { The instructor } r \text { was } \\
\text { concerned about } \\
\text { learning }\end{array}$ \\
\hline & & $\begin{array}{l}\text { The instructor } \\
\text { generally respectful } \\
\text { student learning }\end{array}$ \\
\hline & & $\begin{array}{l}\text { The instructor was } \\
\text { accessible to me outside of } \\
\text { the online course }\end{array}$ \\
\hline & & $\begin{array}{l}\text { The instructor used } \\
\text { Webinar to create a } \\
\text { comfortable learning space }\end{array}$ \\
\hline & & $\begin{array}{l}\text { The instructor personalized } \\
\text { interactions with me } \\
\text { whenever necessary }\end{array}$ \\
\hline \multirow[t]{4}{*}{$\begin{array}{l}\text { Course } \\
\text { Design } \\
\end{array}$} & & $\begin{array}{l}\text { The course was well } \\
\text { organized }\end{array}$ \\
\hline & & $\begin{array}{l}\text { The course was designed to } \\
\text { allow assignments to be } \\
\text { completed across different } \\
\text { learning environments }\end{array}$ \\
\hline & & $\begin{array}{l}\text { The instructor facilitated } \\
\text { the course effectively }\end{array}$ \\
\hline & & $\begin{array}{l}\text { The webinar was used to } \\
\text { create an efficient learning }\end{array}$ \\
\hline
\end{tabular}

\begin{tabular}{|l|l|}
\hline & environment \\
\hline & $\begin{array}{l}\text { The webinar helped me to } \\
\text { learn educational statistics } \\
\text { more quickly }\end{array}$ \\
\hline & $\begin{array}{l}\text { The course was designed to } \\
\text { allow me to take } \\
\text { responsibility for my } \\
\text { learning }\end{array}$ \\
\hline $\begin{array}{l}\text { Satisfact } \\
\text { ion }\end{array}$ & $\begin{array}{l}\text { The online classes were } \\
\text { valuable }\end{array}$ \\
\hline & $\begin{array}{l}\text { Overall, I am satisfied with } \\
\text { the quality of this course }\end{array}$ \\
\hline & $\begin{array}{l}\text { Overall, online learning is } \\
\text { the best learning experience } \\
\text { I have ever had }\end{array}$ \\
\hline & $\begin{array}{l}\text { We are generally given } \\
\text { enough time to understand } \\
\text { the things we have to learn }\end{array}$ \\
\hline & $\begin{array}{l}\text { Taking the online classes } \\
\text { increased my interest in } \\
\text { educational statistics }\end{array}$ \\
\hline & $\begin{array}{l}\text { The online classes } \\
\text { improved } \\
\text { understanding } \\
\text { educational statistics of }\end{array}$ \\
\hline
\end{tabular}

